\title{
FEASIBILITY STUDY OF THE HIGH-YIELDING HORTICULTURE SEEDS BREEDING AGRIBUSINESS DEVELOPMENT IN EAST JAVA
}

\author{
Dwi Retnoningsih ${ }^{1}$ \\ ${ }^{1}$ (Lecturer of Agricultural Economics Department, Agricultural Faculty, Universitas Brawijaya, Indonesia) \\ *corresponding author: dwi_sosek@yahoo.com
}

\begin{abstract}
Horticulture is important sector because it gives significant contribution to the agricultural development in East Java. High-yielding varieties or potential varieties of horticulture demand keeps increasing. That becomes reason towards the importance of feasibility study to the potential varieties of horticulture seeds breeding agribusiness development. The objectives of this research were to understand the potential of various high-yielding varieties of horticulture, economic feasibility, and business marketing chain as well as to analyze the prospect of high-yielding varieties of horticulture seeds breeding agribusiness development. The analysis used in this research was Location Quotient (LQ), supply chain, business feasibility (feasibility study), and AHP (Analytical Hierarchy Process). The research was conducted in 5 (five) locations/regencies. This research conducted by interview to the breeder, user farmer, and seeds seller. The research results showed that potential high-yielding varieties of horticulture seeds in five regencies based on LQ calculation and discussion to the local government are rose apple (Syzygium aqueum), longan fruit, durian, ginger, bird's eye chili or thai chili, orange, potato, and mango. All potential commodities above were feasible to be developed based on R/C ratio, B/C ratio, NPV, and IRR calculation. Marketing chain for those potential commodities was various started from breeder farmer, middleman, farmer group, Regional Owned Enterprises to the user farmer or individual farmer. Prospect of the potential horticulture seeds breeding agribusiness development based on AHP analysis obtained of which varieties that have highest priority in considering horticulture seeds selection are production result attribute, seeds quality, and growth capability.
\end{abstract}

Keywords: Horticulture, seeds breeding, feasibility study, agribusiness development

\section{INTRODUCTION}

Based on Indonesian regulation No. 12 Year of 1992 about Plant Cultivation System Chapter I Article 1 Section 4 stated that plant seed which next called as seed is plant or part of plant that used to grow or cultivate the plant. As planting material, seeds must be high-yielding, which is having high viability, pure, and healthy. The use of qualified seeds has important role in order to improve production quality.

East Java Province is central of potential seeds and largest horticulture production in Indonesia. Seeds production in this area are conducted specifically through breeding mechanism locally.

Supply for national horticulture products are directed to fulfill domestic consumer needs, either through traditional market, modern market, or foreign market (export) (Directorate general of Horticulture, 2012). Horticulture development is implemented using sustainable agribusiness system according to comparative and competitive in rural areas. Sulistyo (2014) stated that domestic horticulture seeds production has competitive quality. Fruit and vegetable seeds - such as chili, tomato, long beans, honeydew, and watermelon able to be produced domestically by $100 \%$ local manpower. Other high-yielding varieties also tend to increase the adaptability to any various threat in the environment (Blum, 2005).

Horticulture agribusiness development, especially seeds breeding, is expected to implement conservation and efficiency principles. It is because the requirement of considering environment and sustainability in agricultural production should be implemented through maintanining soil fertility and precise management of agricultural practices (Cassman, 1999). 
Process of seeds production can be conducted on small piece of land, which is noted as the main characteristic of farmers scale in Java Island. The locations for horticulture seed breeding require near to the water source, good accessibility, flat land condition, and enough sunlight exposure. If there is slopping land, then terracing is good to be applied to reduce land erosion. Those natural resource conservation principles are important to be implemented in order to make land and water resource, as production factor, able to give sustainable benefits and reduce natural resource degradation.

High-yielding horticulture seeds supply in Indonesia are still limited. The improvement attempts of horticulture production to fulfill export needs still face many obstacles. One of them is low seeds production, which has low quality and quantity. These problems may caused by many aspects such as: process of seeds production conducted by unprofessional breeder, less data collection and continual research related to the various types of superior horticulture, mechanism of proper horticulture seeds supply has not been implemented sustainably, no utilization of existed potential agribusiness in horticulture seeds breeding on small scale lands, and less information about prospect of potential horticulture seeds agribusiness development on small scale lands, especially in East Java.

Thus, it is necessary to conduct horticulture agribusiness development, particularly to the seeds breeding. Seeds breeding utilize smale scale land as alternatives in strengthening seed supply in East Java. Recalling the high demand of potential horticulture products in Indonesia, then the implementation of land efficiency principle by using small scale lands for seeds breeding is one effective solution in responding consumer demand. From that point, it is necessary to conduct feasibility study to evaluate potential horticulture seeds breeding agribusiness development, especially on small scale land.

The objectives in this research were to analyze the various potential horticulture varieties with its economic value; analyzing economic feasibility towards potential horticulture seeds breeding agribusiness on small scale lands; analyzing business marketing chain of potential horticulture seeds breeding; and to analyze prospect of potential horticulture seeds breeding agribusiness development on small scale land in East Java.

\section{RESEARCH METHODS Research approach}

This research was conducted in 4 (four) stages including: 1) Analyzing various potential horticulture varieties in the research location; 2) Analyzing business marketing chain of potential horticulture seeds breeding; 3 ) Analyzing economic potential of regional potential horticulture seeds agribusiness; and 4) Analyzing feasibility of superior horticulture seeds agribusiness development in small scale lands in East Java. It

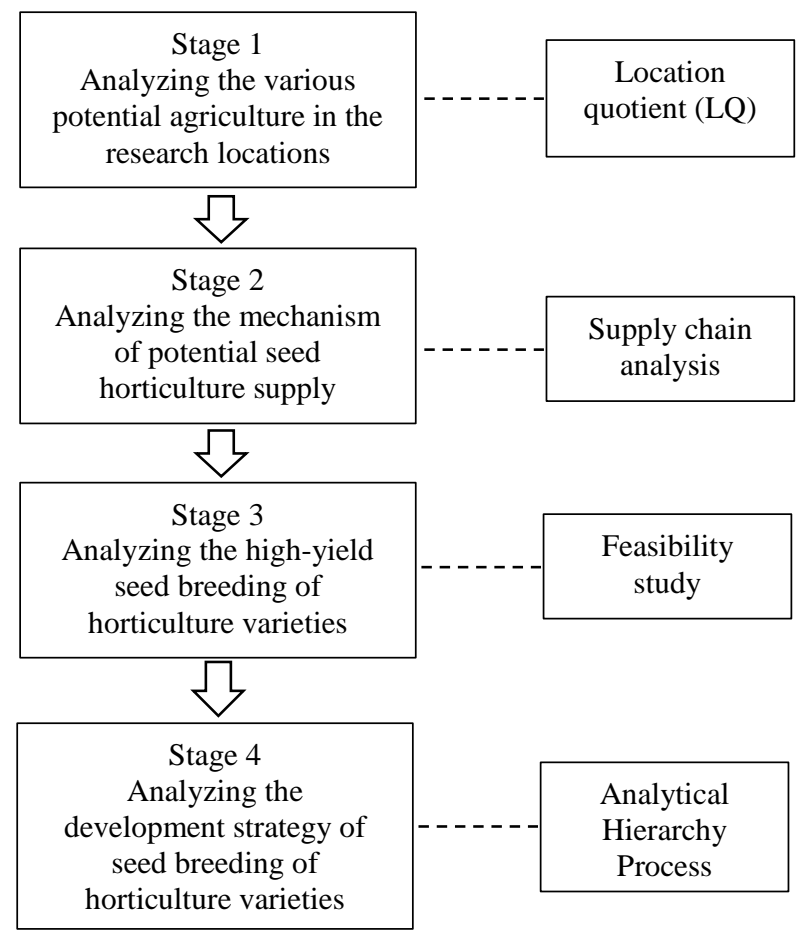

can be explained through Figure 1 below:

Figure 1. Research Stages of potential seeds horticulture

\section{Research location and time}

This research was conducted in 5 (five) locations Trenggalek, Ponorogo, Pacitan, Magetan, and Ngawi Regencies. The time required for finishing this research was 7 (seven) months started from March to October 2015.

\section{Collecting data}

This research used primary and secondary data. Primary data are obtained and collected directly from respondents or key informants in the field through direct interview based on list of questions (questionnaire) that been prepared previously. Secondary data are collected from local 
government data of horticulture production and other related data.

\section{Data analysis}

Data analysis methods used in this research were Location Quotient (LQ), supply chain, feasibility business (feasibility study), and AHP (Analytical Hierarchy Process).

Data analysis in this research was performed based on research stages and research design. Each of research stage as follows: Initial analysis was descriptive analysis of Location Quotient (LQ) analysis.

Formulation of LQ as below:

$$
L Q_{i j}=\frac{X_{i j} / X_{i}}{X_{j} / X}
$$

Where:

$$
\begin{aligned}
L Q_{i j}= & \begin{array}{l}
\text { Index of coefficient for location of } \mathrm{i} \\
\text { village and } \mathrm{j} \text { commodity }
\end{array} \\
X i j= & \begin{array}{l}
\text { Number of production for each } \mathrm{j} \\
\text { commidty in i village }
\end{array} \\
X_{i}= & \text { Total number of production in i village } \\
X_{j}= & \begin{array}{l}
\text { Total number of production for } \mathrm{j} \\
\text { commodity in the District }
\end{array} \\
X \quad & \begin{array}{l}
\text { Total number of production for all } \\
\text { agricultural commodities in the } \\
\text { District }
\end{array}
\end{aligned}
$$

In order to reach the second research objective - how is business marketing chain of potential horticulture seeds breeding on small scale of land it was conducted by descriptive analysis explaining how horticulture seeds breeding in agribusiness management in the research location through supply chain analysis.

Potential horticulture breeding development on small-scale land must be evaluated through feasibility analysis, both technically and financially. This technical and financial analysis performed in order to analyze the success of technological development before it is introduced to the public.

The next stage would result recommendation for technological improvement. On the other hand, financial feasibility analysis was conducted by using Net Present Value (NPV), Internal Rate of Return (IRR), and Benefit Cost Ratio (B/C).

Method used for determining strategies in developing potential horticulture seeds breeding on small-scale land was AHP (Analytical Hierarchy Process). AHP is one of useful methods to choose activities or many alternatives based on certain criteria. AHP method, in this research, used tools analysis software expert choice 11 .

According to Saaty (1991), AHP can be used to take decision such as determining priority, resulting set of alternative, selecting alternative, selecting the best alternative policy, determining many requirements, allocating resources, predicting result and assessing risks, assessing achievement, designing system, planning and solving conflict.

\section{RESULTS AND DISCUSSION General description of research location}

According to BPS (Central Bureau of Statistics) data, superior commodity in Ponorogo Regency is plantation and agriculture sector. Plantation sector has potential commodities of cocoa, sugar cane, coffee, coconut, clove, and cashew. The other commodities are tobacco, rice, cassava, corn, soybean, and peanut.

Potential commodities in Trenggalek Regency, according to BPS data are also clustered as vegetables and the other potential commodities. The potential commodity of vegetable products are long bean, bird's eye chili, eggplant, chayote, and water spinach. While, the fruits commodities are mangosteen and durian.

Pacitan has potential horticulture commodities for vegetables, such as bird's eye chili, green bean, long bean, chili, parkia speciosa (stink bean), and melinjo. While, the potential fruits are mango, banana, jackfruit, durian, papaya, and citrus suhuiensis (siam orange).

Potential horticulture commodities in Magetan Regency, according to BPS data, are cabbage, mustard green, potato, carrot, green bean, tomato, and green onion for vegetable commodity. While, fruit commodities are pomelo orange and strawberry.

Moreover, according to BPS data, Ngawi Regency has horticulture commodities such as onion, green bean, chili, long bean, cucumber, eggplant, mustard green, and tomato. While the fruit commodities in Ngawi Regency are mango, duku fruit, banana, and honeydew.

\section{Potential horticulture commodities}

Location Quotient (LQ) method used to see basic commodity and non-basic commodity from an area and can be used to identify potential commodities, which have comparative superiority $n$ the locations. Assessment criteria to the determination of basic 
and non-basic level as follow: if index score of LQ is larger or equal than one ( $L Q \geq 1$ ), then, the sector is basic sector. In contrast, if index score of LQ is less than one (LQ $<1)$, then the sector is non-basic commodities.

Research result to the potential horticulture with economic value in five Regencies based on LQ calculation as well as seen from discussion result to the related Departments obtained that the potential commodities that suggested to be developed in Ponorogo Regency are rose apple and longan fruit; in Trenggalek Regency are durian and ginger; in Pacitan Regency are ginger, bird's and eye chili; in Magetan Regency are orange and potato; and in Ngawi Regency is mango.

\section{Business feasibility analysis to the seeds breeding agribusiness}

Agribusiness as agricultural business means how using agricultural resources in order to effectively and efficiently gain high profit or benefit. Farmers are called effective in allocating resources if they are able to allocate their resources in appropriate way. Efficient is the term to represent the ability of producer in producing more output at certaint input allocated (Soekartawi, 1995). In the other side, business feasibility study is an analysis in a certain business in order to know whether the business is profitable enough or not (Kasimir and Jakfar, 2010). Silva et al (2007) using monte-carlo simulation in order to evaluate the risk of investment risk, which was based on sensitivity analysis result of production, sales, and input price to determine the level of risk among the production process implemented by the company.

Ponorogo Regency has potential rose apple seeds, it has $\mathrm{R} / \mathrm{C}$ ratio and $\mathrm{B} / \mathrm{C}$ ration larger than 1 means that the business is feasible to be developed, where R/C ratio (2.08) means that every IDR invested by farmers on rose apple seeds commodity for seeds breeding agribusiness will gain revenue of 2.08 times; $\mathrm{B} / \mathrm{C}$ ratio (2.08) means that every investment of IDR 1.00 by farmers will add profit (net benefit) of IDR 2.08; NPV (IDR 222,180,270) means that Net Present Value (NPV) is positive; then, there will be high/positive profit with the establishment of capital interest of $14 \%$ from banking rule in the current time; IRR (27.20) means Internal Rate of Return (IRR) obtained higher percentage than capital interest of $14 \%$. Meanwhile, for longan fruit seeds, it also has R/C ratio and $\mathrm{B} / \mathrm{C}$ ration larger than 1 means that the business is feasible to be developed, where $\mathrm{R} / \mathrm{C}$ ratio (1.74) means that every Rupiah (IDR) invested by farmers on longan fruit seeds commodity towards seeds breeding agribusiness will gain revenue of 1.74 times; $\mathrm{B} / \mathrm{C}$ ratio (1.64) means that every investment of IDR 1.00 by farmers will add profit (net benefit) of IDR 1.64; NPV (IDR 20,367,289) means that Net Present Value (NPV) is positive; then, there will be high/positive profit with the establishment of capital interest of $14 \%$ from banking rule in the current time; IRR (28.26) means Internal Rate of Return (IRR) obtained higher percentage than capital interest of $14 \%$. Therefore, the capital invested in the fruit seeds breeding agribusiness is more profitable than the money is saved in bank.

Trenggalek Regency has potential development of durian seeds, it has $\mathrm{R} / \mathrm{C}$ ratio and $\mathrm{B} / \mathrm{C}$ ration larger than 1 means that the business is feasible to be developed, where $\mathrm{R} / \mathrm{C}$ ratio (1.79) means that every Rupiah (IDR) invested by farmers on durian seeds commodity towards seeds breeding agribusiness will gain revenue of 1.79 times; B/C ratio (1.64) means that every investment of IDR 1.00 by farmers will add profit (net benefit) of IDR 1.64; NPV (IDR 60,800,278) means that Net Present Value (NPV) is positive; then, there will be high/positive profit with the establishment of capital interest of $14 \%$ from banking rule in the current time; IRR (28.42) means Internal Rate of Return (IRR) obtained higher percentage than capital interest of $14 \%$. So, the capital opportunity to be invested is profitable than save the money in bank.

Trenggalek also has potential ginger seeds, it also has $\mathrm{R} / \mathrm{C}$ ratio and $\mathrm{B} / \mathrm{C}$ ration larger than 1 means that the business is feasible to be developed. Where, R/C ratio (1.82) means that every Rupiah (IDR) invested by farmers on ginger seeds commodity towards seeds breeding agribusiness will gain revenue of 1.82 times; $\mathrm{B} / \mathrm{C}$ ratio (1.63) means that every investment of IDR 1.00 by farmers will add profit (net benefit) of IDR 1.63; NPV (IDR 103,344,391) means that Net Present Value (NPV) is positive. IRR (27.80) means Internal Rate of Return (IRR) obtained higher percentage than capital interest of $14 \%$, then it could be stated that the seeds breeding agribusiness is feasible to be developed. The money invested to the ginger seeds breeding agribusiness is more profitable than it is saved to the bank with the highlight that this business managed well. For more information about the analysis is provided in the Tabel 1 and Table 2. 
Table 1. Business Feasibility Analysis to the Seeds Breeding Agribusiness in Ponorogo and Trenggalek

\begin{tabular}{llrrrr}
\hline \multirow{2}{*}{ No } & \multirow{2}{*}{ Business Analysis } & \multicolumn{2}{c}{ Ponorogo Regency } & \multicolumn{2}{c}{ Trenggalek Regency } \\
\cline { 3 - 5 } & & \multicolumn{1}{c}{ Rose Apple } & Longan Fruit & \multicolumn{1}{c}{ Durian } & \multicolumn{1}{c}{ Durian } \\
\hline 1 & Fertilizer (IDR) & $1,500,000$ & $5,000,000$ & 400,000 & 400,000 \\
2 & Labor or Worker (IDR) & $4,500,000$ & $11,500,000$ & $2,400,000$ & $2,400,000$ \\
3 & Total Cost (IDR) & $6,000,000$ & $16,500,000$ & $2,800,000$ & $2,800,000$ \\
4 & Total Revenue (IDR) & $12,500,000$ & $28,700,000$ & $5,000,000$ & $5,000,000$ \\
5 & R/C Ratio & 2.08 & 1.74 & 1.79 & 1.79 \\
6 & NPV (IDR) & $22,180,270$ & $20,367,289$ & $60,800,278$ & $60,800,278$ \\
7 & IRR (\%) & $27.20 \%$ & $28.26 \%$ & $28.42 \%$ & $28.42 \%$ \\
8 & B/C Ratio & 2.08 & 1.64 & 1.64 & 1.64 \\
\hline
\end{tabular}

Table 2. Business Feasibility Analysis to the Seeds Breeding Agribusiness in Pacitan, Magetan and Ngawi

\begin{tabular}{|c|c|c|c|c|c|c|}
\hline \multirow{2}{*}{ No } & \multirow{2}{*}{ Business Analysis } & \multicolumn{2}{|c|}{ Pacitan Regency } & \multicolumn{2}{|c|}{ Magetan Regency } & \multirow{2}{*}{$\begin{array}{c}\text { Ngawi } \\
\text { Regency } \\
\text { Mango }\end{array}$} \\
\hline & & Ginger & $\begin{array}{l}\text { Bird's Eye } \\
\text { Chili }\end{array}$ & Orange & Potato & \\
\hline 1 & Fertilizer (IDR) & $7,500,000$ & $1,000,000$ & $2,500,000$ & $7,500,000$ & 500,000 \\
\hline 2 & Labor or Worker (IDR) & $12,500,000$ & $1,500,000$ & $24,900,000$ & $28,500,000$ & 750,000 \\
\hline 3 & Total Cost (IDR) & $20,000,000$ & $2,500,000$ & $27,400,000$ & $18,000,000$ & $1,250,000$ \\
\hline 4 & Total Revenue (IDR) & $42,200,000$ & $4,800,000$ & $55,800,000$ & $32,550,000$ & $3,200,000$ \\
\hline 5 & R/C Ratio & 2.11 & 1.92 & 2.04 & 1.81 & 2.56 \\
\hline 6 & NPV (IDR) & $218,008,392$ & $27,535,040$ & $284,770,064$ & $133,141,352$ & $19,613,316$ \\
\hline 7 & $\operatorname{IRR}(\%)$ & $29.21 \%$ & $32.97 \%$ & $29.56 \%$ & $28.08 \%$ & $29.62 \%$ \\
\hline 8 & B/C Ratio & 1.66 & 1.76 & 1.67 & 1.64 & 1.67 \\
\hline
\end{tabular}

Pacitan Regency has potential in ginger seeds production, it has $\mathrm{R} / \mathrm{C}$ ratio and $\mathrm{B} / \mathrm{C}$ ration larger than 1 means that the business is feasible to be developed, where $\mathrm{R} / \mathrm{C}$ ratio (2.11) means that every Rupiah (IDR) invested by farmers on ginger seeds commodity towards seeds breeding agribusiness will gain revenue of 2.11 times; $\mathrm{B} / \mathrm{C}$ ratio (1.66) means that every investment of IDR 1.00 by farmers will add profit (net benefit) of IDR 1.66; NPV (IDR 218,008,392) means that Net Present Value (NPV) is positive; then, there will be higher profit established from the capital invested comparing to $14 \%$ annual interest rate of banking; IRR (29.21) means Internal Rate of Return (IRR) obtained higher percentage than capital interest of $14 \%$. Then, the ginger seeds business is feasible to be developed and showed that capital investment to the ginger seeds breeding agribusiness is more profitable than deposit the money in bank. Meanwhile, for bird's eye or thai chili seeds, it also has $\mathrm{R} / \mathrm{C}$ ratio and $\mathrm{B} / \mathrm{C}$ ration larger than 1 means that the business is feasible to be developed, where $\mathrm{R} / \mathrm{C}$ ratio (1.92) means that every Rupiah (IDR) invested by farmers on bird's eye chili seeds commodity towards seeds breeding agribusiness will gain revenue of 1.92 times; $\mathrm{B} / \mathrm{C}$ ratio (1.76) means that every investment of IDR 1.00 by farmers will add profit (net benefit) of IDR 1.76; NPV (IDR 27,535,040) means that Net Present Value (NPV) is positive; IRR (32.97) means Internal Rate of Return (IRR) obtained higher percentage than capital interest of $14 \%$. The IRR value of the Thai Chili seeds is higher than that of ginger seeds.

Feasibility study of orange seeds in Magetan regency shows that it has $\mathrm{R} / \mathrm{C}$ ratio and $\mathrm{B} / \mathrm{C}$ ratio larger than 1 means that the business is feasible to be developed. Additionally, R/C ratio (2.04) means that every Rupiah (IDR) invested by farmers on orange seeds commodity towards seeds breeding agribusiness will gain revenue of 2.04 times. B/C ratio (1.67) means that every investment of IDR 1.00 by farmers will add profit (net benefit) of IDR 1.67. NPV (IDR 284,770,064) means that Net Present Value (NPV) is positive then there exists profit more than cost invested. IRR (29.56) means Internal Rate of Return (IRR) obtained higher percentage than capital interest of $14 \%$. 
Magetan also has potential agribusiness for potato seeds. It also has $\mathrm{R} / \mathrm{C}$ ratio and $\mathrm{B} / \mathrm{C}$ ration larger than 1 means that the business is feasible to be developed, where $\mathrm{R} / \mathrm{C}$ ratio (1.81) means that every Rupiah (IDR) invested by farmers on potato seeds commodity towards seeds breeding agribusiness will gain revenue of 1.81 times. B/C ratio (1.64) means that every investment of IDR 1.00 by farmers will add profit (net benefit) of IDR 1.64. NPV (IDR 133,141,352) means that Net Present Value (NPV) is positive then there will be high/positive profit with the establishment of capital interest of $14 \%$ from banking rule in the current time. IRR (28.08) means Internal Rate of Return (IRR) obtained higher percentage than capital interest of $14 \%$.

Ngawi Regency has potential mango seeds. It has $\mathrm{R} / \mathrm{C}$ ratio and $\mathrm{B} / \mathrm{C}$ ration larger than 1 means that the business is feasible to be developed. Where, R/C ratio (2.56) means that every Rupiah (IDR) invested by farmers on mango seeds commodity towards seeds breeding agribusiness will gain revenue of 2.56 times. $\mathrm{B} / \mathrm{C}$ ratio (1.67) means that every investment of IDR 1.00 by farmers will add profit (net benefit) of IDR 1.67. NPV (IDR 19,613,316) means that Net Present Value (NPV) is positive then there will be high/positive profit with the establishment of capital interest of $14 \%$ from bank. IRR (29.62) means Internal Rate of Return (IRR) obtained higher percentage than capital interest of $14 \%$.

Based on calculation and explanation above, it can be found that potential commodity seeds breeding agribusiness in five Regencies give profit or benefit to the breeder farmers as well as, in general, able to improve local people economy.

\section{Supply chain analysis of seeds breeding agribusiness}

According to Heizer and Render (2010), supply chain management is an integration of supply and service activities, the change of intermediate goods to be final goods, also delivery processes to customers. Supply mechanism of potential seeds horticulture commodities in Ponorogo, Trenggalek, Pacitan, Magetan, and Ngawi Regency, in general, is started from seeds production of local breeder farmer in each area. Then, from breeder farmer those come to middlemen, farmer group, Regional Owned Enterprises (BUMD) and finally to the user farmer or individual farmer. Supply mechanism of longan fruit, potato, and mango seeds supply is the shortest mechanism started from breeder farmers that go directly to the user farmer or individual farmer.

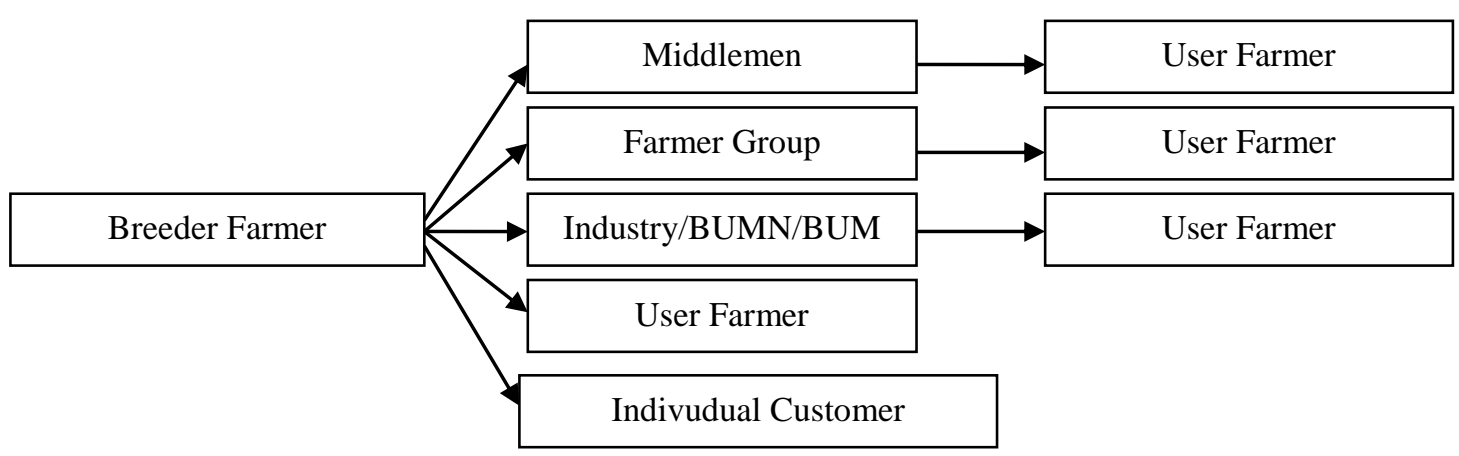

Figure 1. Longest Marketing Chain of Superior Seeds Commodity

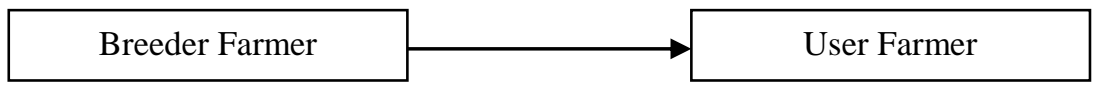

Figure 2. Shortest Markting Chain of Superior Seeds Commodity

In Ponorogo Regency, supply mechanism of rose apple seeds is started from breeder farmer then distributed to the middlemen, farmer group, Regional Owned Enterprises (BUMD) to the user farmer or individual farmer; and there is also short mechanism started from breeder farmer directly to the user or individual farmer. While, supply mechanism of longan fruit seeds supply majority is started from breeder farmer directly to the user or individual farmer.

In Trenggalek Regency, supply mechanism of durian seeds supply is started from breeder 
farmer then distributed to the farmer group, industry/company to the user farmer or individual farmer; and there is also the short mechanism started from breeder farmer directly to the user or individual farmer.

In Pacitan Regency, supply mechanism of ginger seeds supply is started from breeder farmer then distributed to the middlemen, farmer group, Regional Owned Enterprises (BUMD) to the user farmer or individual farmer; and there is also short mechanism, which is started from breeder farmer directly to the user or individual farmer. While the mechanism of bird's eye chili seeds is started from breeder farmer then distributed to the middlemen, farmer group, industry/company to the user farmer or individual farmer; and there is also short mechanism started from breeder farmer directly to the user or individual farmer.

In Magetan Regency, supply mechanism of orange seeds is started from breeder farmer, Regional Owned Enterprises (BUMD) to the user farmer or individual farmer. While potato seeds supply has shortest mechanism, which is started from breeder farmer directly to the user or individual farmer. In Ngawi Regency, mango seeds supply also has shortest mechanism process started from breeder farmer directly to the user or individual farmer

\section{Prospect of potential horticulture seeds breeding agribusiness development}

Process of financial feasibility analysis had been performed and gave description that superior commodity seeds breeding agribusiness in five Regencies - Ponorogo, Trenggalek, Pacitan, Magetan, and Ngawi. Those commodities are feasible to be developed as source of profit for local people. While, supply chain of seeds supply in each Regency had been found that there are agents in the market of horticulture seeds who help distribution of seeds to the user farmers. AHP analysis performed to take decision effectively over complex problems by simplifying and quickly make a decision with many considerations to establish which variables have highest priority that affect the best result in certain situation. The result of this analysis is to describe the potential horticulture seeds breeding agribusiness which has highest prospect in each Regency.

Consistency ratio from the assessment of seeds selection attribute showed the score less than 0.1 means that assessment given by farmers to the attributes had good assessment consistency. Farmers who perform assessment of seeds attribute considered be able to compare all assessment attributes consistently.

User farmers in Ponorogo select rose apple and longan fruit seeds attribute of the quality as main attribute due to fact that the quality of output is generated from the high quality of seed. Then, it will be easy to gain production optimally.

User farmers in Trenggalek select attribute of production technology for durian and ginger seeds. It is because they believe that production technology attribute is the main factor that affects directly to the user farmer's income. This is the same thing with the farmers in Pacitan and Magetan Regencies, who prefer to select high-yield production as the prominent factor considered.

While, in Ngawi Regency, main consideration of user farmers in selecting mango seeds was growth capability attribute. Growth capability will heavily affected the success of mango agribusiness. The better growth capability of mango seeds bought, the faster financially feedback gained. More information is provided in Table 3 and Table 4.

\section{Supporting agents in the potential horticulture seeds breeding development}

Agriculture sector is an activity, which still has good prospect to be developed. Agriculture, which has orientation in commercial way, is formed as agribusiness. Moreover, agribusiness as a system is a complete system started from sub-system of production facilities and agricultural equipments supply, sub-system of agribusiness, sub-system of management or agroindustry, and sub-system of marketing. In order to make these sub-systems run appropriately then it needs supports from subsystem of facilities and infrastructures institution and supporting sub-system of the development. Therefore, it is necessary to form the mechanism in a way that build appropriate assistance pattern in order to get agribusiness development appropriately. 
Table 3. Weight of Attribute Importance Level in Panorogo and Trenggalek

\begin{tabular}{lllccc}
\hline \multirow{2}{*}{ No } & & \multicolumn{2}{c}{ Ponorogo Regency } & \multicolumn{2}{c}{ Trenggalek Regency } \\
\cline { 3 - 5 } & & Weight & Level & Weight & Level \\
\hline 1 & Production & 0.1664 & 1 & 0.125 & 5 \\
2 & Pest and Disease Resistance & 0.1490 & 3 & 0.201 & 2 \\
3 & Growth Capability & 0.1501 & 2 & 0.221 & 1 \\
4 & Seeds Quality & 0.1350 & 4 & 0.182 & 3 \\
5 & Packaged Seeds Volume & 0.0790 & 7 & 0.019 & 8 \\
6 & Interesting Package & 0.0605 & 9 & 0.008 & 9 \\
7 & Availability and Accessibility & 0.1100 & 5 & 0.121 & 4 \\
8 & Certification & 0.0850 & 6 & 0.102 & 7 \\
9 & Promotion & 0.0650 & 8 & 0.021 & $\mathbf{1 . 0 0 0}$ \\
\hline Total Weight of Attribute & $\mathbf{1 . 0 0 0}$ & $\mathbf{0 . 0 4 0 0}$ & & $\mathbf{0 . 0 3 4}$ \\
\hline Consistency Ratio $(\mathbf{C R})$ & & &
\end{tabular}

Table 4. Weight of Attribute Importance Level in Ponorogo, Trenggalek, and Pacitan

\begin{tabular}{|c|c|c|c|c|c|c|c|}
\hline \multirow[t]{2}{*}{ No } & \multirow[t]{2}{*}{ Attribute } & \multicolumn{2}{|c|}{ Ponorogo Regency } & \multicolumn{2}{|c|}{ Trenggalek Regency } & \multicolumn{2}{|c|}{ Pacitan Regency } \\
\hline & & Weight & Level & Weight & Level & Weight & Level \\
\hline 1 & Production & 0.195 & 2 & 0.1255 & 1 & 0.1290 & 1 \\
\hline 2 & $\begin{array}{l}\text { Pest and Disease } \\
\text { Resistance }\end{array}$ & 0.112 & 4 & 0.1225 & 2 & 0.1250 & 2 \\
\hline 3 & Growth Capability & 0.133 & 3 & 0.1180 & 4 & 0.1210 & 3 \\
\hline 4 & Seeds Quality & 0.291 & 1 & 0.1165 & 5 & 0.1150 & 4 \\
\hline 5 & Packaged Seeds Volume & 0.011 & 8 & 0.0950 & 8 & 0.0900 & 9 \\
\hline 6 & Interesting Package & 0.062 & 9 & 0.0920 & 9 & 0.1100 & 6 \\
\hline 7 & $\begin{array}{l}\text { Availability and } \\
\text { Accessibility }\end{array}$ & 0.075 & 6 & 0.0980 & 7 & 0.0960 & 8 \\
\hline 8 & Certification & 0.021 & 7 & 0.1215 & 3 & 0.1120 & 5 \\
\hline 9 & Promotion & 0.100 & 5 & 0.1110 & 6 & 0.1020 & 7 \\
\hline \multicolumn{2}{|c|}{ Total Weight of Attribute } & 1.000 & & 1.000 & & 1.000 & \\
\hline \multicolumn{2}{|c|}{ Consistency Ratio (CR) } & \multicolumn{2}{|c|}{0.023} & \multicolumn{2}{|c|}{0.025} & \multicolumn{2}{|c|}{0.035} \\
\hline
\end{tabular}

Assistance mechanism of potential horticulture seeds breeding agribusiness development on small-scale lands should be built through the mechanism presented in Figure 3.

Some important points can be made as strategic activities, such as developing competitive advantage and using comparative advantage in the seeds products, empowering seeds breeding agribusiness through technology improvement and financial gain, implementing cooperative institution among the breeder. In the aspect of marketing, the small-scale breeders need to develop marketing strategy for the product so the adoption and the access of the high-yield varieties will be much easyier of user farmers. The government should also help in developing seeds breeding agribusiness resources, developing central development of agribusiness sector, developing infrastructures for seeds breeding agribusiness, and establishing integrated policy to the seeds breeding agribusiness. The other important factor is also related to regulation and control of government related to quality of the seed produced by the breeders. 


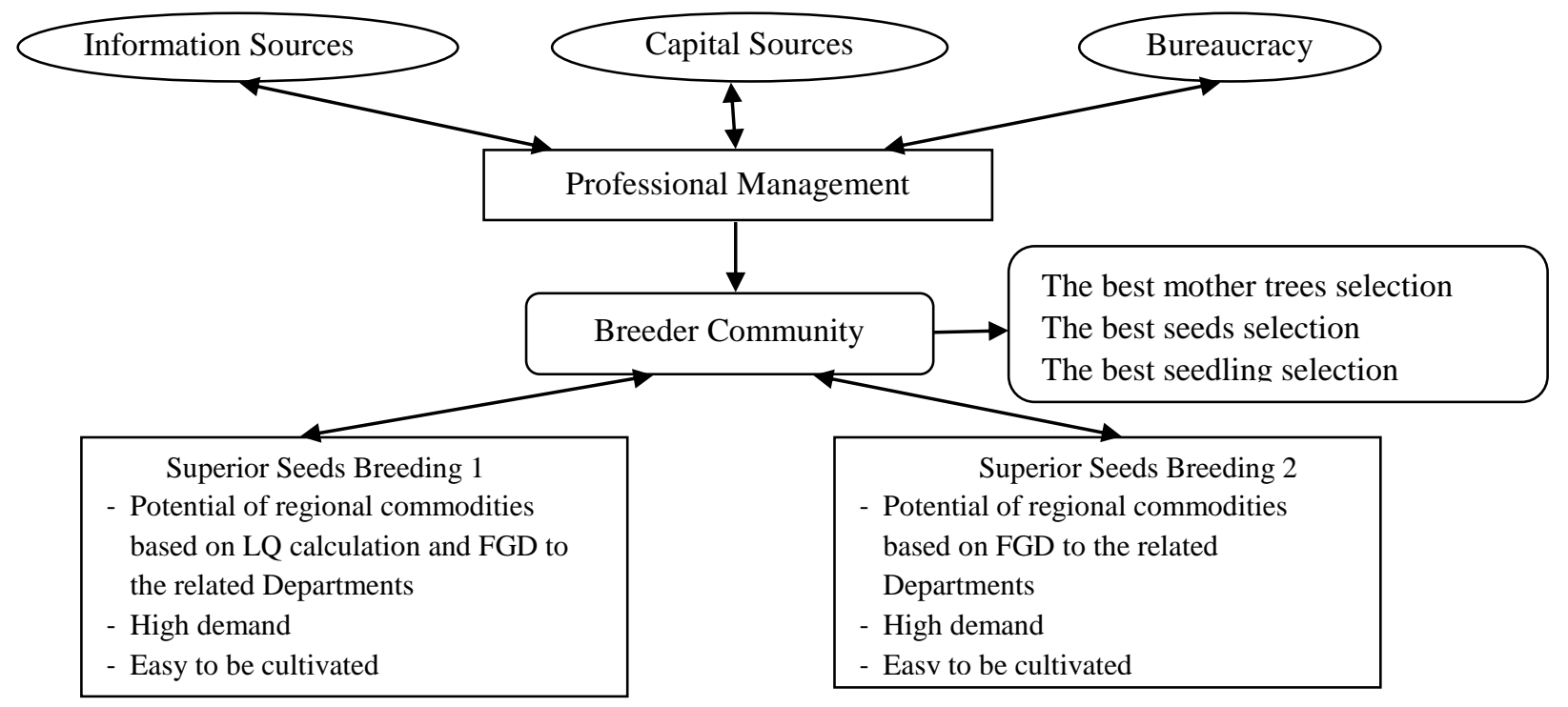

Figure 3. Agribusiness Design of Breeder Community

In order to be able in managing the agribusiness appropriately; then, it needs information including information about cultivation technique, technology, market demand, and market price as well. Despite information, it also needs financial support, thus in the breeding development there will be easier way in accessing capitals from financial institutions. And also, it needs government role in encouraging the realization of professional breeder community that able to deal with market needs.

\section{CONCLUSION AND SUGGESTIONS}

Potential commodities in Ponorogo Regency are rose apple and longan fruit; Trenggalek Regency are durian and ginger; Pacitan Regency are ginger and bird's eye chili; Magetan Regency are orange and potato; while Ngawi Regency is mango.

Based on calculation of business feasibility, it could be found that potential commodities for seeds breeding agribusiness in five Regencies above are profitable. The breeder farmers will potentially be able to improve local people economy in general through these breeding activities.

Marketing chain of seeds commodities in five Regencies above are vary started from breeder farmer, middlemen, farmer group, Regional Owned Enterprises (BUMD), to the user famer or individual farmer. And there is also shortest mechanism started from breeder farmers that go directly to the user farmer or individual farmer.
Potential horticulture seeds breeding agribusiness development on small-scale lands in five Regencies of East Java performed by using AHP analysis concludes that farmers of horticulture seeds user in Trenggalek, Pacitan, and Magetan Regency for durian, ginger, bird's eye chili, and orange choose high-yield production attribute as main consideration of horticulture seeds selection. While, farmers of rose apple and longan fruit seeds user in Ponorogo Regency consider seeds quality attribute as main consideration of horticulture seeds selection. Furthermore, the farmers of mango seeds user in Ngawi Regency that saw growth capability attribute as main consideration of horticulture seeds selection.

Based on potential horticulture with economic value in five Regencies and followed by coordination to the related government agencies such as Ministry of Agriculture of Horticulture Sector and Ministry of Environment and Forestry resulted in: (1) After it was found the economic potential of horticulture seeds breeding agribusiness in five Regencies, it can be recommended to conduct coordination to the related financial institutions such as cooperative and banking in order to give easier way for breeder to access capital by using information of business feasibility that been performed to the seeds breeding agribusiness. Besides, it should give information and coordination to the other Regional 
Government such as People Empowerment Agency and Ministry of Trade and Industry to conduct social and economic empowerment in developing seeds breeding agribusiness; (2) the next was found process mechanism of potential commodity seeds supply in each Regency then it can be recommended that Ministry of Agriculture conduct promotion to the public as well as competent companies should encourage breeding agribusiness, thus the seeds marketing able to be distributed largely and sustainably; (3) From prospect of superior horticulture seeds breeding agribusiness development on narrow lands, it can be recommended that Ministry of Agriculture should conduct assistance and counseling related to the seeds quality, because seeds users take priority on seeds quality; (4) By assistance pattern of superior horticulture seeds breeding agribusiness development on narrow lands, it can be recommended that Ministry of Agriculture should conduct assistance systematically and structurally. Assistance can be performed gradually by cooperation with other government institution and also private sectors, thus seeds breeding agribusiness development can be realized appropriately.

\section{REFERENCES}

Cassman, K. G. (1999). Ecological intensification of cereal production systems: yield potential, soil quality, and precision agriculture. Proceedings of the National Academy of Sciences, 96(11), 5952-5959.
Ditbuah. Hortikultura. 2012. Petunjuk Umum Program Peningkatan Produksi, Produktivitas dan Mutu Produk Hortikultura Berkelanjutan TA 2013. Jakarta.

Heizer, Jay \& Barry Render. (2010). Manajemen Operasi. Edisi Ketujuh Buku 1. Jakarta: Salemba Empat

Kasmir, Jakfar. 2010. Studi Kelayakan Bisnis. Jakarta (ID): Kencana.

Saaty, T. L. 1991. Pengambilan Keputusan Bagi Para Pemimpin. Setiono, Penerjemah. Jakarta: Institut Pendidikan dan Pembinaan Manajemen (IPPM) dan PT. Pustaka Binaman Pressindo. Terjemahan dari: Decision Making for Leaders The Analytical Hierarchy Process for Decision in Complex World

Soekartawi, 1995. Analisis Usahatani. UI Press. Jakarta.

Sulistio. 2014. Benih Hortikultura Produksi Lokal Mendominasi Secara Nasional. http://bandung.bisnis.com. Diakses Januari 2015

Blum, A. (2005). Drought resistance, water-use efficiency, and yield potential-are they compatible, dissonant, or mutually exclusive?. Crop and Pasture Science, 56(11), 1159-1168.

Silva, C. B., do Vale, S. M. L. R., Pinto, F. A., Müller, C. A., \& Moura, A. D. (2007). The economic feasibility of precision agriculture in Mato Grosso do Sul State, Brazil: a case study. Precision Agriculture, 8(6), 255-265. 